\title{
Microwave-Assisted Pyrolysis of Fuel Oil for Hydrocarbons Upgrading
}

\author{
Suksun Amornraksa ${ }^{1 *}$, and Thanida Sritangthong ${ }^{1}$ \\ ${ }^{1}$ The Sirindhorn International Thai-German Graduate School of Engineering (TGGS), King Mongkut's University of Technology \\ North Bangkok, Bangkok, Thailand
}

\begin{abstract}
By-product upgrading is crucial in hydrocarbon processing industries as it can increase the competitiveness of the business. This research investigated opportunity to upgrade fuel oil by-product obtained from olefins production by using microwave pyrolysis. A lab-scale quartz reactor filled with placed inside a 1,200 watts household microwave oven was used for the experiments. Coconut-based activated carbon was used as a microwave receptor. Microwave powers were varied at $600 \mathrm{~W}, 840 \mathrm{~W}$ and $1,200 \mathrm{~W}$ to adjust cracking temperature between $800^{\circ} \mathrm{C}$ and $900^{\circ} \mathrm{C}$. The effect of residence time was investigated by adjusting flow rate of $\mathrm{N}_{2}$ carrier gas. The chemical compositions and product yields were analyzed by using gas chromatography (GC) and gas chromatography/mass spectrometry (GC/MS). It was revealed that hydrogen, carbon monoxide, carbon dioxide and hydrocarbon gaseous product (alkanes, naphthenics and alkenes) were produced as the main products. For liquid products, the main compositions were cycloalkenes and polycyclic aromatic groups.
\end{abstract}

\section{Introduction}

By-product upgrading is a crucial strategy in hydrocarbon industries as it can increase overall profit margin and competitiveness of the business. Several thermal conversion techniques, with or without catalysts, are applied to convert hydrocarbons in petrochemical industry such as hydrotreating, hydrocracking and pyrolysis. Pyrolysis is a thermal degradation of molecules in the absence of oxygen. It breaks down molecules of raw material and converts it to different reactive intermediates, in forms of solid (char), liquid and gases. Pyrolysis typically occurs at temperatures above $430^{\circ} \mathrm{C}\left(800^{\circ} \mathrm{F}\right)$. The pyrolysis reaction is very complex and involves a huge number of main and side reactions, especially when dealing with a mixture of hydrocarbon feed. In general, the reaction consists of three main steps i.e. initiation, propagation, and termination. An example of pyrolysis reaction of hexane $(\mathrm{C} 6 \mathrm{H} 14)$ by free radical mechanism can be represented as follows [1]:

Initiation

$$
\mathrm{C}_{6} \mathrm{H}_{14} \rightarrow \mathrm{C}_{2} \mathrm{H}_{5}{ }^{\circ}+\mathrm{C}_{4} \mathrm{H}_{9}^{\circ}
$$

Propagation

$$
\begin{aligned}
& \mathrm{C}_{2} \mathrm{H}_{5}{ }^{\circ}+\mathrm{C}_{6} \mathrm{H}_{14} \rightarrow \mathrm{C}_{2} \mathrm{H}_{6}+\mathrm{C}_{6} \mathrm{H}_{13}{ }^{\circ} \\
& \mathrm{C}_{4} \mathrm{H}_{9}{ }^{\circ}+\mathrm{C}_{6} \mathrm{H}_{14} \rightarrow \mathrm{C}_{4} \mathrm{H}_{10}+\mathrm{C}_{6} \mathrm{H}_{13}{ }^{\circ} \\
& \mathrm{C}_{4} \mathrm{H}_{9}{ }^{\circ} \rightarrow \mathrm{C}_{3} \mathrm{H}_{6}+\mathrm{CH}_{3}{ }^{\circ} \\
& \mathrm{C}_{6} \mathrm{H}_{13}{ }^{\circ} \rightarrow \mathrm{C}_{4} \mathrm{H}_{8}+\mathrm{C}_{2} \mathrm{H}_{5}^{\circ} \text { (+other products) }
\end{aligned}
$$

Termination

$$
\mathrm{C}_{2} \mathrm{H}_{5}{ }^{\circ}+\mathrm{CH}_{3}^{\circ} \rightarrow \mathrm{C}_{3} \mathrm{H}_{8}
$$

In pyrolysis process, heat is supplied by means of conventional heating i.e. through a burner. However, in recent years, alternative heat source like microwave heating has gained much attention from researchers [2-4]. There are many advantages of the microwave heating. For example, it is selective heating with very high heating rate. It requires a short start-up time and therefore a quick start-stop operation is possible [6]. It is an innovative and unique method that has the ability to process a wide variety of materials [6]. Many researches on the application of microwave revealed that the microwave heating is highly energy-efficient. Furthermore, the reaction time required to complete the reaction could be significantly shortened [7]. However, in some cases, a microwave receptor such as activated carbon, char or graphite may be needed when handling with non-reactive material [8].

There are many parameters that influence the microwave pyrolysis process such as composition of raw material, residence time and temperature. Bolotov et. al. [9] studied the microwave pyrolysis with black oil (hydrocarbons $\mathrm{C} 16+$ ) and heavy oil (hydrocarbons with large fraction of heavy paraffins). Sibunit (porous carbon material) was used as a catalyst. They found that the heavy oil feed produced much higher gaseous products than the black oil. Therefore, the compositions of raw materials affect to product yield in pyrolysis process.

Reaction temperature is a very important operating parameter as they have very strong effect on product distribution of pyrolysis process [10]. Wu et. al. [11]

\footnotetext{
* Corresponding author: suksun.a.cpe@tggs-bangkok.org
} 
studied the microwave pyrolysis of wood sawdust under different microwave power (600, 900, and $1200 \mathrm{~W})$. When temperature or microwave power was increased, the result showed that the liquid yield and gas yield were also increased. On the other hand, the amount of char was remarkably decreased.

Residence time is another important parameter. Long residence time promotes secondary and subsequent reactions which, in turn, affects to the product distribution. Lam et. al. [12] studied the effect of $\mathrm{N}_{2}$ feed rate on the product distribution of microwave pyrolysis of waste oil. They found that by changing $\mathrm{N}_{2}$ feed rate from 100 to $250 \mathrm{~mL} / \mathrm{min}$, the yield of pyrolysis oils could be increased. This is because high $\mathrm{N}_{2}$ flow rate increases the pressure in the reactor. The cracked gas products are removed from the reactor more rapidly and thus a shorter residence time. Therefore, the secondary and subsequent reactions that convert the intermediate pyrolysis oils are not occurred. So, the yield of pyrolysis oils is large while the yields of pyrolysis gases and solid residues are small.

\section{Materials and methods}

\subsection{Materials}

A sample of heavy hydrocarbon used in this study was obtained from an olefins plant in Thailand. It is a bottom product of quench oil tower and has the quality equivalent to light fuel oil. The physical properties of heavy hydrocarbon sample were illustrated in Table 1.

Table 1. Physical properties of heavy hydrocarbon sample

\begin{tabular}{|c|c|c|c|c|}
\hline & S.G. & $\begin{array}{c}\text { Viscosity } \\
\left(\mathbf{m m}^{2} / \mathbf{s}\right), \\
\mathbf{1 0 0}^{\circ} \mathbf{C}\end{array}$ & BMCI & $\begin{array}{c}\text { Flash } \\
\text { point } \\
\left({ }^{\circ} \mathbf{C}\right)\end{array}$ \\
\hline $\begin{array}{c}\text { Heavy } \\
\text { hydrocarbon }\end{array}$ & 1.0758 & 6.021 & 125.7 & 94 \\
\hline
\end{tabular}

The microwave receptor used in this study was coconutbased activated carbon pellet, which had apparent density $0.48 \mathrm{~g} / \mathrm{cc}$ and moisture $8 \% \mathrm{w} / \mathrm{w}$.

\subsection{Methods}

The experiments were performed by using a lab-scale microwave pyrolysis system. The system comprised of microwave oven, quartz reactor, thermocouple (K-type), condenser unit, liquid collector and Tedlar ${ }^{\circledR}$ gas sampling bag. A schematic diagram of the system was shown in Fig. 1. The main apparatus was a household microwave oven (SHARP R-380i, multi-mode). The microwave generator was a $1200 \mathrm{~W}$ magnetron type, having a microwave frequency of 2,450 MHz. The size of quartz reactor was $27 \mathrm{~cm}$ in length and $45 \mathrm{~mm}$ for outer diameter. It was inserted into a hole on top of the microwave oven. The top of the reactor was inserted with thermocouple, feed inlet tube and $\mathrm{N}_{2}$ inlet tube.

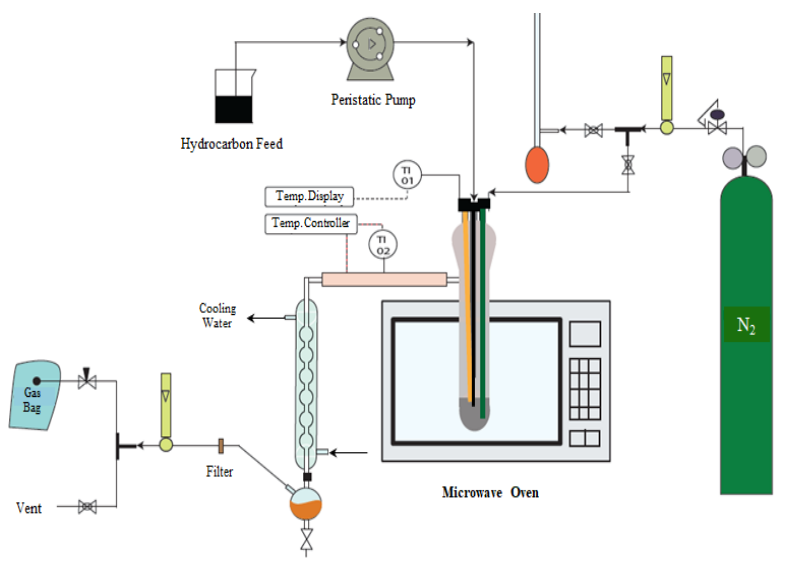

Fig. 1. Schematic diagram of microwave pyrolysis system.

The experiments were conducted by placing coconutbased activated carbon $30 \mathrm{~g}$ in quartz reactor. Then, $99.5 \% \mathrm{~N}_{2}$ carrier gas was fed through the reactor at flow rate of $60 \mathrm{~mL} / \mathrm{min}$ for $20 \mathrm{~min}$ to ensure that no oxygen was remained in the reactor. After that, microwave oven was turned on at given microwave power. After 10 minutes, the temperature inside the reactor became stable and the heavy hydrocarbon sample was introduced to the reactor. The feed rate of sample was set at $2 \mathrm{~mL} / \mathrm{min}$ and the experiment was conducted for 20 minutes.

The effect of microwave power was investigated by adjusting the power output of the microwave oven from 600,840 to $1200 \mathrm{~W}$ with constant $\mathrm{N}_{2}$ flow rate at 60 $\mathrm{mL} / \mathrm{min}$. It should be noted that the power output of $840 \mathrm{~W}$ was the default setting by the machine, which cannot be changed without a special modification to the machine.

To study the effect of residence time, the $\mathrm{N}_{2}$ flow rate was varied from 30,60 and $120 \mathrm{~mL} / \mathrm{min}$ with constant microwave power of $840 \mathrm{~W}$. Condensable volatiles were collected in laboratory glass bottles. The non-condensable volatiles passed through $0.5 \mu \mathrm{m}$ filter before being collected in $1 \mathrm{~L}$ Tedlar ${ }^{\circledR}$ gas sampling bag. The yields of solid and liquid products were determined by weighing each fraction while the yield of gas product was obtained by mass balance.

\subsection{Product analysis}

The gaseous products collected in the gas sampling bag was analyzed by two separate gas chromatographs, one for $\mathrm{H}_{2}, \mathrm{CO}$, and $\mathrm{CO}_{2}$ and another for light hydrocarbon gases $\left(\mathrm{C}_{1}-\mathrm{C}_{5}\right)$. The $\mathrm{H}_{2}, \mathrm{CO}$, and $\mathrm{CO}_{2}$ were analyzed by a Shimadzu GC-2014 series equipped with thermal conductivity detector (TCD). The $\mathrm{C}_{1}-\mathrm{C}_{5}$ hydrocarbons were analyzed by using GC (Agilent Technologies 7890B) with PoraPLOT Q-HT column and flame ionization detector (FID). 


\section{Results and discussion}

\subsection{Effect of microwave power}

\subsubsection{Effect to temperature}

The effect of microwave power to the reaction temperature was studied at no feed condition. The microwave power were varied from 600,840 and $1200 \mathrm{~W}$ and the temperature profile of coconut activated carbon, where the pyrolysis takes place, was measured and illustrated in Fig. 2. It was found that the temperature of coconut activated carbon was increased very rapidly in a short period of time. The results clearly show the advantage of microwave heating as it only requires a short start-up time for operation. At steady state, the average temperatures of coconut-based activated carbon around 800,850 and $900{ }^{\circ} \mathrm{C}$ were obtained from the microwave power of 600,840 and $1200 \mathrm{~W}$, respectively. It can be noticed that the microwave power had a little effect to the temperature as it did not significantly change the temperature. The maximum temperature is likely to be limited by the type of material that was used as a microwave receptor. It is expected that different type of microwave receptor such as silicon carbide will provide a better result.

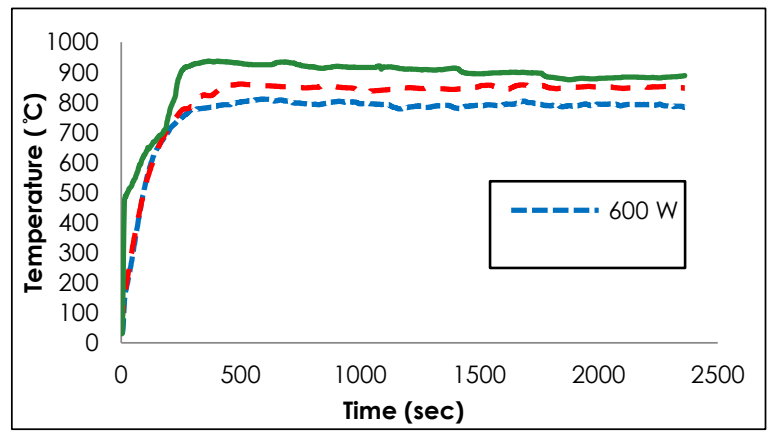

Fig. 2. Temperature profile inside reactor using coconut-based activated carbon for different microwave power.

\subsubsection{Effect to product yield}

The product distribution of solid, liquid and gas phase obtained from different microwave powers is illustrated in Fig 3. In general, it was found that when the microwave power was increased, the solid yield was decreased while the gaseous products were increased. This is simply because at a high reaction temperature, the cracking severity is higher, and so smaller molecules are tended to be produced. As a result, the gas product yields were increased while the solid yields were decreased, when the microwave power was increased.

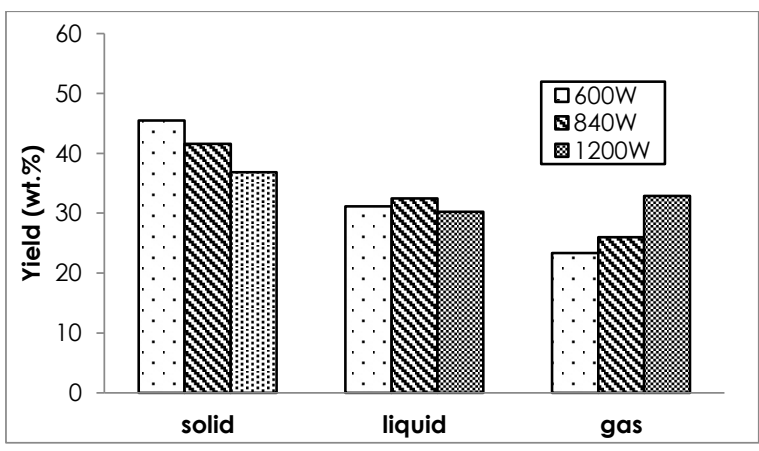

Fig. 3. Product distribution for different microwave powers.

The product yields of $\mathrm{H}_{2}, \mathrm{CO}$ and $\mathrm{CO}_{2}$ in the gaseous products obtained from the microwave pyrolysis at different microwave power were shown in Fig. 4. The result explicated that the increasing of microwave power increased the $\mathrm{H}_{2}$ yield. It was clear that increasing microwave power led to increased temperature. This promoted the secondary reactions of hydrocarbon cracking, leading to the higher production of $\mathrm{H}_{2}$. The $\mathrm{CO}$ yields were quite similar while the $\mathrm{CO}_{2}$ yields were decreased, when increasing the microwave powers.

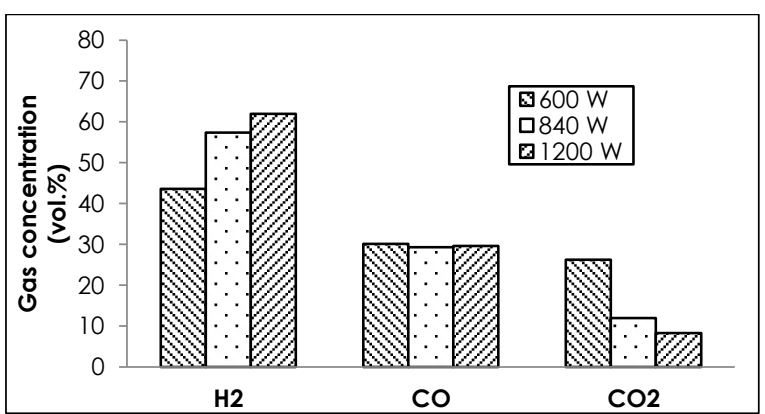

Fig. 4. Gas concentration analysis for different microwave powers.

Because pyrolysis reactions are very complex and a number of primary and secondary reactions are involved. So, it is very difficult to predict the final products that could obtain. Zhang et.al. [13] proposed the pyrolysis reactions that involve the formation and depletion of $\mathrm{H}_{2}$, $\mathrm{CO}$ and $\mathrm{CO}_{2}$ as follows.

$$
\begin{aligned}
& \mathrm{Tar} \rightarrow \mathrm{CH}_{4}+\mathrm{H}_{2} \mathrm{O}+\mathrm{C}_{\mathrm{m}} \mathrm{H}_{\mathrm{n}}+\mathrm{H}_{2} \\
& \mathrm{CH}_{4}+\mathrm{H}_{2} \mathrm{O} \rightarrow \mathrm{CO}+3 \mathrm{H}_{2} \\
& \mathrm{CO}+\mathrm{H}_{2} \mathrm{O} \rightarrow \mathrm{CO}_{2}+\mathrm{H}_{2} \\
& \mathrm{C}+\mathrm{H}_{2} \mathrm{O} \rightarrow \mathrm{CO}+\mathrm{H}_{2} \\
& \mathrm{C}+\mathrm{CO}_{2} \rightarrow 2 \mathrm{CO} \\
& \mathrm{C}+2 \mathrm{H}_{2} \rightarrow \mathrm{CH}_{4} \\
& \mathrm{CH}_{4}+\mathrm{CO}_{2} \rightarrow 2 \mathrm{CO}+2 \mathrm{H}_{2} \\
& \mathrm{C}_{\mathrm{m}} \mathrm{H}_{\mathrm{n}}+2 \mathrm{nH}_{2} \mathrm{O} \rightarrow \mathrm{nCO}_{2}+[2 \mathrm{n}+(\mathrm{m} / 2)] \mathrm{H}_{2}
\end{aligned}
$$




$$
\begin{aligned}
& \mathrm{C}_{\mathrm{m}} \mathrm{H}_{\mathrm{n}}+\mathrm{nH}_{2} \mathrm{O} \rightarrow \mathrm{nCO}+[\mathrm{n}+(\mathrm{m} / 2)] \mathrm{H}_{2} \\
& \mathrm{CO}+3 \mathrm{H}_{2} \leftrightarrow \mathrm{CH}_{4}+\mathrm{H}_{2} \mathrm{O} \\
& \mathrm{CO}_{2}+4 \mathrm{H}_{2} \leftrightarrow \mathrm{CH}_{4}+2 \mathrm{H}_{2} \mathrm{O}
\end{aligned}
$$

From above reactions, it can be concluded that $\mathrm{CO}_{2}$ is likely to be converted to $\mathrm{CO}$ and $\mathrm{H}_{2}$, particularly at high temperature.

The hydrocarbon gaseous products obtained from the microwave pyrolysis contained mostly alkanes, naphthenics, and alkenes. Even though they represented a potential of high value chemicals, the quantity were relatively small. The gaseous products were analyzed and the result was shown in Fig. 5. It was revealed that the yields of all products were generally decreased when the microwave power was increased.

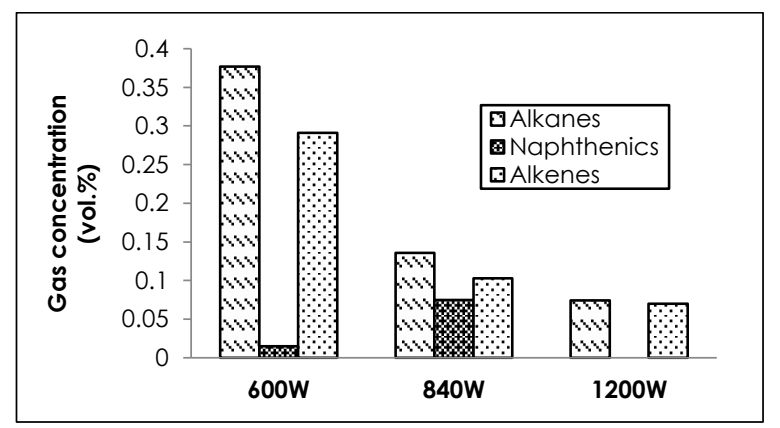

Fig. 5. Gas concentration analysis of light hydrocarbons for different microwave powers.

The increase in microwave power promoted secondary reactions and therefore it led to the decrease in aliphatic hydrocarbon content. As generally known, pyrolysis process is dominant by free radical-induced random scission mechanism. Hydrocarbon radicals are produced during the reaction. The produced radicals break carbon-carbon bonds of nearby molecules by taking the hydrogen atoms out. At higher temperature, the reaction rate is increased and thus heavy n-alkanes and alkenes are converted more to lighter components. This result was in good agreement with the results shown in Fig. 3 which demonstrated that more gases were produced at higher temperature.

The effect of microwave power on the product distribution of cycloalkenes and aromatic hydrocarbons were illustrated in Fig. 6. It can be noticed that the amount of cycloalkenes products were significantly lower that of the aromatic hydrocarbons. This result indicated that the cycloalkenes were not a stable form at high temperature $\left(>800^{\circ} \mathrm{C}\right)$. They tended to be converted into aromatics, more stable form of non-aliphatic hydrocarbon. Since $\mathrm{H}_{2}$ was also produced from the conversion of cycloalkenes to aromatics, the total amount of $\mathrm{H}_{2}$ product was expected to be high. This expectation was confirmed by the previous result in Fig. 4.

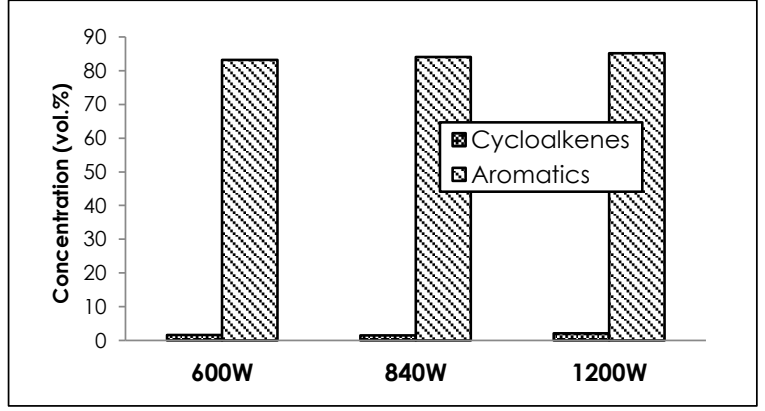

Fig. 6. Product distribution of liquid products for different microwave powers.

\subsection{Effect of flow rate of $\mathrm{N}_{2}$ carrier gas}

The effect of $\mathrm{N}_{2}$ gas flow rate to product distribution of solid, liquid and gas was investigated at the microwave power of $840 \mathrm{~W}$. The results were shown in Fig. 7. In general, it can be seen that the solid and liquid products tended to increase while gaseous product tended to decrease, when the $\mathrm{N}_{2}$ flow rate was increased. The explanation for these results were quite simple. As the $\mathrm{N}_{2}$ flow rate was increased, the residence time of cracked gas products in the reactor was decreased. As a result, the secondary and side reactions in the reactor were decreased. Therefore, large molecules such as solid and liquid hydrocarbons did not have enough time to be converted further to smaller molecules i.e. the gaseous products.

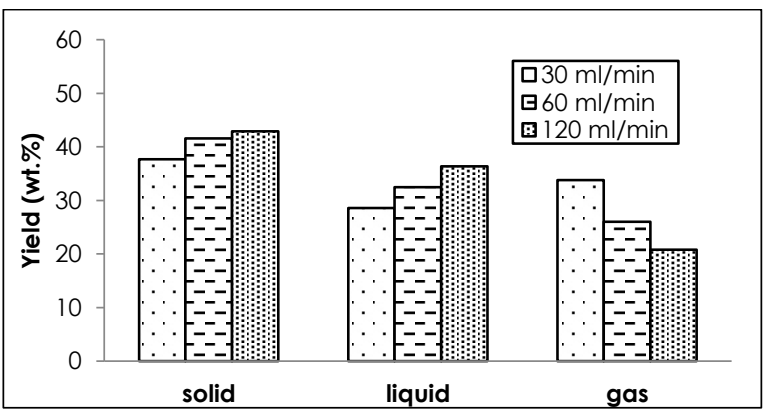

Fig. 7. Product distribution for different $\mathrm{N}_{2}$ gas flow rates.

The effect of $\mathrm{N}_{2}$ flow rate on the product distribution of $\mathrm{H}_{2}, \mathrm{CO}$ and $\mathrm{CO}_{2}$ was investigated and shown in Fig. 8. Interestingly, the $\mathrm{H}_{2}$ content was increased while the $\mathrm{CO}$ content was decreased when increasing the $\mathrm{N}_{2}$ flow rate. It may be caused by the reaction between $\mathrm{CO}_{2}$ and carbonaceous material to produce more $\mathrm{CO}$ at high temperature as shown in Equation 5. $\mathrm{CO}$ and $\mathrm{H}_{2}$ were also consumed for $\mathrm{CH}_{4}$ formation as shown in Equation 10. Nevertheless, the yield of $\mathrm{CO}_{2}$ was found to be relatively unaffected by the $\mathrm{N}_{2}$ carrier gas flow rates. To find out the explanation for this phenomenon, it may be necessary to study the mechanisms of all reaction involved. 


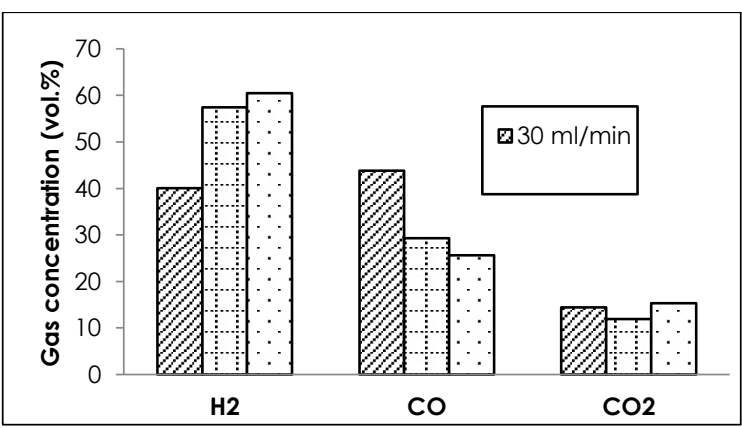

Fig. 8. Gas concentration analysis for different $\mathrm{N}_{2}$ flow rates.

The effect of $\mathrm{N}_{2}$ flow rate to the product distribution of aliphatic hydrocarbons was illustrated in Fig. 9. First of all, it was found that the all the components were generally decreased as the $\mathrm{N}_{2}$ flow rate increased. At the $\mathrm{N}_{2}$ flow rate of $120 \mathrm{~mL} / \mathrm{min}$, both alkanes and alkenes were increased while the naphthetics was not found. As mention earlier, the increase of $\mathrm{N}_{2}$ flow rate led to the decrease of residence time of the cracked gas products in the reactor. This consequently led to the decrease of aliphatic content in the cracked gas products.

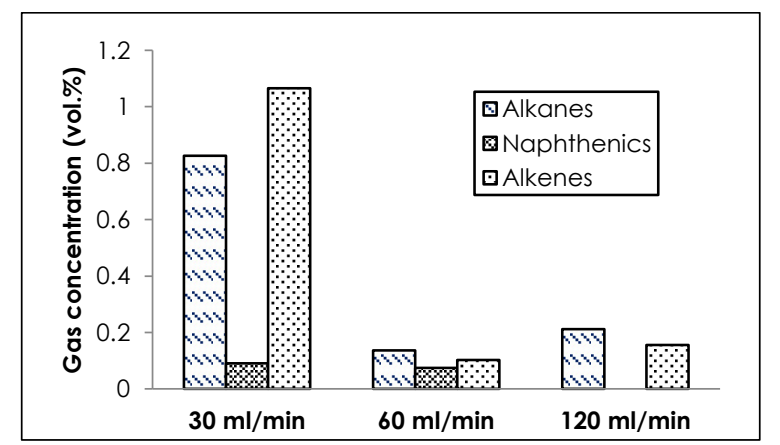

Fig. 9. Gas concentration analysis of light hydrocarbons for different $\mathrm{N}_{2}$ gas flow rates.

The effect of $\mathrm{N}_{2}$ flow rate to the product distribution of cycloalkenes and aromatic hydrocarbons in liquid product was illustrated in Fig. 10. As the $\mathrm{N}_{2}$ flow rate was increased, the residence time was decreased. This resulted in an increase in cycloalkenes and aromatic contents at $\mathrm{N}_{2}$ flow rate $60 \mathrm{~mL} / \mathrm{min}$ and $120 \mathrm{~mL} / \mathrm{min}$. In addition, the shorter residence time decreased the conversion of cycloalkenes and aromatic to gas products.

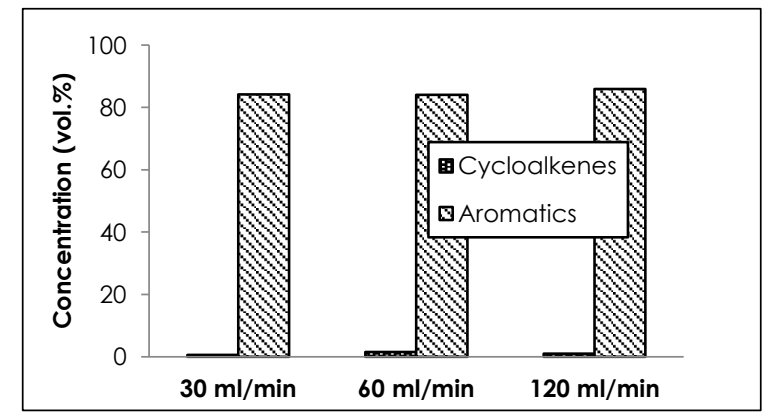

Fig. 10. Product distribution of liquid products for different $\mathrm{N}_{2}$ flow rates.

\section{Conclusion}

This research has demonstrated opportunity for by-product upgrading of heavy hydrocarbon using microwaveassisted pyrolysis. The heavy hydrocarbon sample used in this work was obtained from an olefin plant in Thailand. The microwave powers and $\mathrm{N}_{2}$ carrier gas flow rate were varied to investigate the consequences on the product distribution.

The products produced by the microwave pyrolysis of fuel oil consist of gas and liquid components. $\mathrm{H}_{2}$ was a main gaseous product in this experiment. High temperature and long residence time was found to promote the secondary cracking reactions of hydrocarbon molecules. The product compositions found in liquid product consisted of cycloalkenes and aromatic compounds. These products were produced by condensation and aromatization reactions as a result of high temperature and short residence time condition.

Temperature and residence time had strong effect on product yield of microwave pyrolysis of heavy hydrocarbon. The results of olefins, aromatic, and other products that were produced could give some insight information for further feasibility study of upgrading the heavy hydrocarbon by-product.

In conclusion, the microwave pyrolysis is a promising method that could be used to upgrade lowvalue heavy hydrocarbon. It showed a good potential to be studied and developed further for the application of hydrocarbon processing.

This research was funded by King Mongkut's University of Technology North Bangkok. Contract no. KMUTNB-GOV-58-40. The authors are grateful for Thailand institute of scientific and technological research (TISTR) for their support in gas composition analysis.

\section{References}

1. I.D. Mall, Lecture4: Thermal Cracking, Visbreaking and Delayed Coking, Available at : https://nptel.ac.in/ content/storage2/nptel_data3 $/ \mathrm{html} / \mathrm{mhrd} / \mathrm{ict} / \mathrm{text} / 103$ 107081/lec18.pdf

2. J.A. Menéndez, M. Inguanzo, J.J. Pís, Water Res. 36, 3261 (2002)

3. J.A. Menéndez, A. Domínguez, M. Inguanzo, J.J. Pís, JAAP. 71, 657 (2004)

4. A. Domínguez, J.A. Menéndez, M. Inguanzo, J.J. Pís, Bioresour Technol. 97, 1185 (2006)

5. J.A. Menéndez, A. Arenillas, B. Fidalgo, Y. Fernández, L. Zubizarreta, E.G. Calvo, J.M. Bermúdez, Fuel Process. Technol. 91, 1 (2010)

6. K.E. Haque, Int J Miner Process. 57, 1 (1999)

7. J.A. Menéndez, M. Inguanzo, J.J. Pís, Water Res. 36, 3261-3264 (2002)

8. J.A. Menéndez, A. Domínguez, M. Inguanzo, J.J. Pís, JAAP. 71, 657 (2004)

9. V.A. Bolotov, Evgeny I. Udalov, Valentin N. Parmon, JMPEE. 46, 39 (2012) 
10. Y. Chen, H. Yang, X. Wang, S. Zhang, H. Chen, Bioresour Technol. 107, 411 (2012)

11. C. Wu, V.L. Budarin, M.J. Gronnow, M.D. Bruyn, J.A. Onwudili, J.H. Clark, P.T. Williams, JAAP. 107, 276 (2014)
12. S.S. Lam, A.D. Russell, C.L.Lee, H.A. Chase, Fuel. 92, 327 (2012)

13. S. Zhang, Q. Dong, L. Zhang, Y. Xiong, Bioresour Technol. 191, 17 (2015) 